\title{
Reagan seeks ratification of treaty with Soviet Union
}

\section{Washington}

President Reagan has decided to negotiate a protocol with the Soviet Union strengthening verification provisions in two treaties on underground nuclear explosions signed by both countries in 1974 and 1976 but never ratified by the United States.

Senator Charles Percy (Republican, Illinois), chairman of the Senate Foreign Relations Committee, announced on 16 February that the White House had informed him that negotiations could.start "in a matter of weeks" if the Soviet Union is willing. The decision implies that the President does not want to ratify the treaties as they are, a goal sought by Percy and several other members of the Senate.

Percy had asked the President's nominee as director of the Arms Control and Disarmament Agency, Kenneth L. Adelman, whose nomination is in trouble, to try to break the logjam that has delayed the Administration's ruling on the treaties for two years. Although they are technically already before the Senate for ratification, the Senate is unlikely to proceed without support from the White House.

Percy has been concerned about the two treaties since his visit to Moscow in 1980 on taking over as Foreign Relations Committee chairman. On his return, he announced that ratification of the two treaties by the Senate was important to maintain US credibility with the Soviet Union on arms control. The more important agreement on strategic arms, Salt II, signed by both sides, has also never been ratified by the United States.

The Threshold Test Ban Treaty (TTBT) and the Treaty on Peaceful Nuclear Explosions (PNE) were negotiated in the NixonFord era and signed in 1974 and 1976 respectively. They prohibit either side from detonating underground nuclear blasts of any kind over 150 kilotons in yield and are to be verified primarily by the seismic detection nets that detect distant tremors in the Earth and distinguish earthquake signals from those of large explosions.

The PNE treaty has an added attraction to US arms controllers in that each side agrees to some form of on-site inspection. Since combined explosions of more than 150 kilotons are allowed provided advance notice is given to the other side, the other side may then verify with its own equipment on site to be sure that no single explosion in the group exceeds the 150 kiloton limit. The clusters feature was included in the PNE treaty because of Soviet interest in large earth-moving projects.

Since the treaties were negotiated, however, each side has accused the other violations. On twelve occasions, US monitors have recorded tremors that could have originated from blasts of more than 150 kilotons, but detection limits and seismic calibrations are not sufficiently refined to be sure.

The Soviet Union has denied that any of the tests exceeded the treaty limit and claimed that on five occasions blasts at the Nevada test site in the United States exceeded the limit. The United States denied these charges. Whether such claims and counterclaims would sour a future negotiation over verification of the treaties is not clear. Neither is it clear why the President, after two years of delay, has decided to renegotiate. One reason given by Administration officials is that the history of violations proves that existing provisions are inadequate.

On the other hand, the opponents of arms control often criticize arms control agreements on the grounds that verification is inadequate. These people could hae agreed to the idea of renegotiation as a way to avoid having to ratify the treaties.

The most hopeful possibility is that the two sides will agree to incorporate in the verification system for the threshold testban treaty the system of up to ten automatic seismic stations on each other's territory agreed upon in 1980 as part of the comprehensive test-ban treaty. Technically, these stations would have broken new ground by their use of public-key cryptography as a means of giving each side access to the data collected by the other.

Any reopening of the test-ban treaty through talks with the Soviet Union could run into another problem, the modernization of inter-continental ballistic missiles (ICBM). Many Soviet warheads have yields above 150 kiloton, and Soviet weapons-builders could well take advantage of a hiatus in the treaties to test these higher yield weapons. Last week there were reports that the Soviet Union had tested a second new ICBM. Under Salt II, each side is allowed to test only one new ICBM type.

Besides the two test limit treaties, senators on the Foreign Relations Committee are also interested in reviving negotiations towards a comprehensive test-ban treaty. President Carter had put the two treaties on a back burner while trying instead to complete a comprehensive test bank. But the test ban negotiations were broken off in 1980 after the Soviet invasion of Afghanistan.

A resolution introduced in the Senate by Edward Kennedy (Democrat, Massachusetts), Charles Mathias (Republican, Maryland) and others urges the Administration to resume negotiations on a comprehensive test ban. It also urges the Administration to ask the Senate to ratify the two nuclear test limit treaties.

Deborah Shapley
French research Contract work

\section{Sophia-Antipolis}

FRENCH researchers may have to take an examination half-way through their careers, if they wish to advance to a higher post, according to a new "contract of employment" being prepared by the Ministry of Research and Industry in Paris.

This requirement is a step towards meritocracy and democracy in French science - or so its perpetrators claim. It will help separate advancement by age and seniority from advancement by merit, and provide a relatively uniform standard by which researchers can be judged.

An outline of the new contract was presented here last week at a conference on French science policy by Claude Kordon, himself a researcher. Kordon is not a politician but despite his protests that the new contract not completely defined, it is clear he is flying the government's kite.

The contract, says Kordon, would divide researchers employed by the principal French research organizations into two classes. In each class, a contract of employment would have two components: one guaranteeing "'minimal career", offering a slow growth of salary with age, and another allowing acceleration along the scale according to "evaluation of work".

The lowest class would end at the present maître de recherche. Examination would allow transition to the top class, which would end at the present highest level of directeur de recherche. The allocation of these top grades would be done by the Minister of Research and Industry himself "to avoid any devaluation of the title". He would be advised by the Conseil Superieur de la Recherche et de la Technologie.

The only dangers, argued Kordon, were that too many careers would be accelerated, thus destroying the objective of the structure; or that too few senior jobs would be created to allow sufficient acceleration.

One problem is that since last year's law on research, the job of a researcher has been extended to include not only research but also science popularization and general education, and the application of his or her work. But no criteria have been established to judge these functions, or the relative weight they should take compared with research itself. So the question of how to evaluate a researcher has become even more difficult.

The second problem lies in the fact that the new career structure will separate the evaluation of salary from the evaluation of title - and from the offer of positions. There will thus be three evaluation systems running in parallel, some local and some central (based in Paris), plus an exam. A similar system, but this time with three classes of career and two examinations, will operate for technicians and senior technicians (engineers).

Robert Walgate 